\section{Anticonvulsant activity of thymoquinone and its structural analogues}

\author{
Damião P. de Sousa, ${ }^{* 1}$ Franklin F. F. Nóbrega, ${ }^{2}$ Camila C. M. \\ P. Santos, ${ }^{2}$ Rubens B. Benedito, ${ }^{2}$ Ygor W. Vieira, ${ }^{3}$ Marciana $P$. \\ Uliana, ${ }^{3}$ Timothy J. Brocksom, ${ }^{3}$ Reinaldo N. de Almeida ${ }^{2}$
}

${ }^{1}$ Laboratório de Química de Produtos Naturais e Sintéticos Bioativos, Departamento de Fisiologia, Universidade Federal de Sergipe, Brazil,

${ }^{2}$ Laboratório de Tecnologia Farmacêutica, Universidade Federal da Paraíba, Brazil,

${ }^{3}$ Laboratório de Química Bio-Orgânica, Departamento de Química, Universidade Federal de São Carlos, Brazil.
Revista Brasileira de Farmacognosia Brazilian Journal of Pharmacognosy 21(3): 427-431, May./Jun. 2011

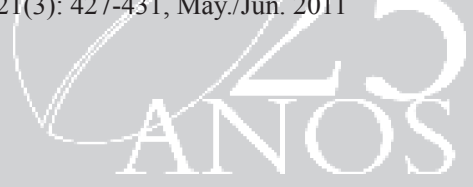

\section{Article}

Received 19 Apr 2010 Accepted 25 Oct 2010 Available online 18 Mar 2011

\begin{abstract}
It has been widely reported that the crude oil of Nigella sativa L., Ranunculaceae, seeds and its major chemical component thymoquinone present anticonvulsant activity. These facts led us to verify the pharmacological potential of five structurally related para-benzoquinones on the pentylenotetrazol-induced seizures model, and establish the structural characteristics that influence the anticonvulsant activity of thymoquinone. The unsubstituted para-benzoquinone was the compound that exhibited the highest potency, while 2-methyl-p-benzoquinone was inactive. It was found that the presence of alkyl groups attached to the ring influence the pharmacological activity of the para-benzoquinones. In addition, the number, position, and size of these groups change the anticonvulsant potency of the compounds.
\end{abstract}

Keywords: quinones anticonvulsant activity seizures central nervous system structure-activity relationships oils

ISSN 0102-695X doi: $10.1590 / \mathrm{S} 0102-695 \mathrm{X} 2011005000040$

\section{Introduction}

Diseases of the central nervous system are amongst the most common ailments afflicting mankind. Epilepsy is the term used for a group of disorders characterized by recurrent spontaneous seizures (Engel, 1995) and up to 5\% of the world population develops epilepsy in their lifetime (Sander \& Shorvon, 1996). There appear to be many causes for epilepsy, but epileptic seizures are characterized by simultaneous firing of cortical neurons. Therapeutic use of antiepileptic drugs has focused on lowering $\mathrm{Na}^{+}$, $\mathrm{K}^{+}$, or $\mathrm{Ca}^{2+}$ flux in neurons, inhibiting glutamate $(\mathrm{Glu})$ neurotransmission, or promoting $\gamma$-aminobutyric acid (GABA) activity at $\mathrm{Cl}^{-}$channels (Clement et al., 2004). Several studies have shown the anticonvulsant activity of natural products (Almeida et al., 2003). A significant number of herbal medication and dietary supplements are used for treating patients with neurological or psychiatric complaints. Some of these products may be anticonvulsant and thus of possible benefit in patients with epilepsy. There are more studies that report anti-seizure activity of a nonallopathic preparation with animal models of epilepsy (Tyagi \& Delanty, 2003). Evidence for the pharmacological effect of these components on experimental tests has been provided (De Sousa et al., 2006; 2007; De Almeida et al., 2008).
Quinones are ubiquitous in nature and constitute an important class of naturally occurring compounds found in plants, fungi, and bacteria. Current human exposure to quinones occurs via the diet as well as clinically. Benzoquinones are potentially derivable by oxidation of suitable phenolic compounds. Many of these benzoquinones have important biochemical functions in electron transport systems for respiration or photosynthesis. Natural products frequently occur containing the benzoquinone sub-structural unit within the global structure, as can be exemplified by vitamins $\mathrm{K}_{1}$ and $\mathrm{K}_{2}$, co-enzyme $\mathrm{Q}$ (ubiquinone), and in many terpenes (Dewick 2001). The pharmacological properties attributed to naturally occurring quinones are thus well established. For example, thymoquinone, the principal active constituent of Nigella sativa seeds, presents anticonvulsant activity in the petit mal epilepsy (Hosseinzadeh \& Parvardeh, 2004). N. sativa has been traditionally used as a natural remedy for a number of illnesses and conditions such as diabetes, inflammation, bronchitis, fever, and influenza (Ali \& Blunden, 2003). Mechanism of action studies have shown that this quinone exerts its anticonvulsant activity through the stimulation of opioid receptors in the central nervous system (Hosseinzadeh et al., 2005). These facts led us to verify the pharmacological potential of 
five structurally related para-benzoquinones on the pentylenotetrazol (PTZ)-induced seizures model, and establish the structural characteristics that influence the anticonvulsant activity of thymoquinone.

\section{Materials and Methods}

\section{General}

${ }^{1} \mathrm{H}$ and ${ }^{13} \mathrm{C}$ NMR spectra were obtained on a Bruker DRX-400 spectrometer at 400 and $100 \mathrm{MHz}$ respectively. Chemical shifts are quoted in ppm downfield from a tetramethylsilane internal standard. Melting points were determined on a Micro Química model APF 301 apparatus and are uncorrected. Solvents and reagents were used directly from the manufacturer, or purified when required by standard procedures. The six phenols and $\left[\mathrm{Co}^{\mathrm{II}}(\right.$ salen $\left.)\right]$ are commercially available products (Aldrich) and used as obtained.

General procedure for the metal complex catalyzed oxidations

The phenol (1.0 mmol), was dissolved in DMF $(5 \mathrm{~mL})$, and oxygen was bubbled into the reaction mixture for a few minutes, and then an oxygen atmosphere was maintained with a balloon. The $\mathrm{Co}^{\mathrm{II}}$ (salen) catalyst $(6 \%$ mol) was added, and the reaction mixture stirred at room temperature for $3 \mathrm{~h}$. Further catalyst $(6 \% \mathrm{~mol})$ was added and the reaction mixture stirred for another $3 \mathrm{~h}$ at room temperature. The process was repeated once more, for a total addition of $18 \%$ mol catalyst, and a total reaction time of $24 \mathrm{~h}$. Ether $(20 \mathrm{~mL})$ was added and the black mixture washed with $0.1 \mathrm{molL}^{-1} \mathrm{HCl}(2 \times 10 \mathrm{~mL})$, water and brine. The ethereal solution was dried over anhydrous $\mathrm{MgSO}_{4}$ and the solvent evaporated. The residue was usually purified by sublimation (or by flash column chromatography when necessary, using as eluent a mixture of 9:1 hexane:ethyl acetate) (Dockal et al. 1985; Uliana et al. 2008), and the corresponding para-benzoquinones 1-4 were obtained with $30-95 \%$ yield (Table 1).

\section{Animals}

Male Swiss mice (28-34 g) were obtained from our research animal facility. The animals were maintained at constant room temperature $\left(23+1{ }^{\circ} \mathrm{C}\right)$ and on a $12 / 12 \mathrm{~h}$ light-dark cycle (light from 6 a.m. to 6 p.m.), with free access to food and water. All behavioral observations were conducted between 8:00 and 12:00 h and approved by the Institution's Ethics Committee for the Care and Use of Animals.

PTZ-induced convulsions
Mice were divided into eight groups $(n=8)$. The control and positive control groups received 5\% Tween 80 or diazepam (DZP) (4 mg/kg, i.p.), respectively. The remaining groups received an injection of the benzoquinones at dose of $80 \mathrm{mg} / \mathrm{kg}$, i.p. Thirty minutes after drug administration, the mice were treated with PTZ (i.p.) at a dose of $60 \mathrm{mg} / \mathrm{kg}$ and observed for at least $15 \mathrm{~min}$ to detect the occurrence of the first episode of forelimb clonus (Swinyard et al., 1989).

\section{Statistical Analysis}

The statistical analysis was performed using analysis of variance (ANOVA), followed by Dunnett's multiple comparison test. A probability level of 0.05 was regarded as significant.

\section{Results and Discussion}

Nigella sativa L., Ranunculaceae, seeds have been used for thousands of years as a protective and curative remedy for numerous disorders. It has been demonstrated that the crude oil prepared from the seeds, and its major chemical component thymoquinone, exhibit anticonvulsant activity (Ilhan et al., 2005; Hosseinzadeh \& Parvardeh, 2004; Hosseinzadeh et al., 2005). Beneficial interaction of thymoquinone and sodium valproate in experimental models of epilepsy was demonstrated. This benzoquinone combined with sodium valproate increases its antiepileptic response (Raza et al., 2006). Considering the importance of benzoquinones as candidates for anticonvulsant drugs, we report in this comparative study, the findings from the assessment of the anticonvulsant activity of thymoquinone and their structural analogues using PTZ-induced seizures model.

The quinones were synthesized using as starting materials a non-substituted phenol, three di-alkylsubstituted phenols, and two mono-alkyl-substituted phenols with standard $\mathrm{O}_{2}$ and $\left[\mathrm{Co}^{\mathrm{II}}(\right.$ salen) $]$. Table 1 and Scheme 1 shows the products of the oxidation of the phenols against the metal-ligand catalyst. The parabenzoquinone products are all known compounds, and identification was performed by comparison of NMR spectral data, as well as melting point determinations.

Among the compounds tested, five parabenzoquinones were found to have anticonvulsant action (Figure 1). The unsubstituted para-benzoquinone 1 (no alkyl groups) $(p<0.001)$, was the compound that presented the highest potency. This result shows that the absence of alkyl groups increase the anticonvulsant activity of para-benzoquinones. In fact, there was a significant decrease of pharmacological activity in the other para-benzoquinones with regard to compound 1. Comparing 2-methyl-p-benzoquinone 2 (methyl 


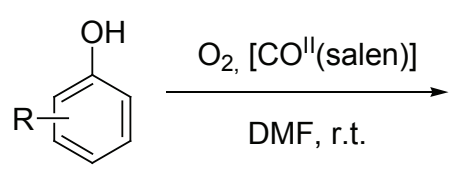<smiles>O=C1C=CC(=O)C=C1</smiles><smiles>CC1=CC(=O)C=CC1=O</smiles><smiles>CC(C)C1=CC(=O)C=CC1=O</smiles><smiles>[131In]</smiles><smiles>[13CH3][14CH3]</smiles>

$3(34 \%)$<smiles>CC1=CC(=O)C=C(C)C1=O</smiles><smiles>CC1=CC(=O)C(C)=CC1=O</smiles><smiles>CC1=CC(=O)C(C(C)C)=CC1=O</smiles>

$4(95 \%)$

$5(90 \%)$

$6(93 \%)$

Scheme 1. Oxidation of mono-phenols to para-benzoquinones.

Table 1. Characterization data of prepared compounds

\begin{tabular}{|c|c|}
\hline Compound & Physical and spectral data \\
\hline$p$-Benzoquinone (1) & $\begin{array}{l}\text { Yield: } 30 \% \text {; Mp } 110-114{ }^{\circ} \mathrm{C} \text {; Lit. Mp: } 113-115^{\circ} \mathrm{C} \text { (Acros Organics, 2007/2008); CAS 106- } \\
\left.51-4{ }^{\circ} \mathrm{C} ;{ }^{1} \mathrm{H} \text { NMR }\left(\mathrm{CDCl}_{3} / \mathrm{TMS}\right) \delta 6.79(4 \mathrm{H}, \mathrm{s}) ;{ }^{13} \mathrm{C} \text { NMR (CDCl } / \mathrm{TMS}\right): \delta 136.6,187.2 .\end{array}$ \\
\hline 2-Methyl-p-benzoquinone (2) & $\begin{array}{l}\text { Yield: } 54 \% \text {; Mp } 65-68^{\circ} \mathrm{C} \text {; Lit. Mp } 67-70{ }^{\circ} \mathrm{C}(\text { Saladino et al., } 2002) \text {; CAS 553-97-9; }{ }^{1} \mathrm{H} \text { NMR } \\
\left(\mathrm{CDCl}_{3} / \mathrm{TMS}\right): \delta 1.90(3 \mathrm{H}, \mathrm{s}), 6.62(1 \mathrm{H}, \mathrm{s}), 6.75(1 \mathrm{H}, \mathrm{d}, J=10.1 \mathrm{~Hz}), 6.77(1 \mathrm{H}, \mathrm{d}, J=10.1 \mathrm{~Hz}) \text {; } \\
{ }^{13} \mathrm{C} \mathrm{NMR}\left(\mathrm{CDCl}{ }_{3} / \mathrm{TMS}\right) \delta 15.8,133.3,136.4,136.5,145.9,187.5,187.7 .\end{array}$ \\
\hline 2-Isopropyl-p-benzoquinone (3) & $\begin{array}{l}\left.\text { Yield: } 34 \% \text {; Mp } 57-60{ }^{\circ} \mathrm{C} \text {; Lit. Mp: } 54-58^{\circ} \mathrm{C} \text { (Acros Organics, } 2007 / 2008\right) \text {; CAS 15232-10-7; } \\
{ }^{1} \mathrm{H} \text { NMR }\left(\mathrm{CDCl}_{3} / \mathrm{TMS}\right): \delta 1.14(6 \mathrm{H}, \mathrm{d}, J=6.8 \mathrm{~Hz}), 3.05(1 \mathrm{H}, \mathrm{dhept}, J=6.8 ; 1.1 \mathrm{~Hz}), 6.55(1 \mathrm{H} \text {, } \\
\mathrm{d}, J=1.1 \mathrm{~Hz}), 6.73(1 \mathrm{H}, \mathrm{d}, J=2.5 \mathrm{~Hz}), 6.74(1 \mathrm{H}, \mathrm{d}, J=2.5 \mathrm{~Hz}) ;{ }^{13} \mathrm{C} \mathrm{NMR}\left(\mathrm{CDCl}_{3} / \mathrm{TMS}\right): \delta 16.5 \text {, } \\
26.2,130.3,135.9,137.0,154.9,187.1,188.1 .\end{array}$ \\
\hline 2,6-Dimethyl-p-benzoquinone (4) & $\begin{array}{l}\text { Yield: } 95 \% \text {; Mp } 69-72{ }^{\circ} \mathrm{C} \text {; Lit. Mp } 71-73{ }^{\circ} \mathrm{C}\left(\text { Barton et al., 1988); CAS 527-61-7; }{ }^{1} \mathrm{H} \text { NMR }\right. \\
\left(\mathrm{CDCl}_{3} / \mathrm{TMS}\right): \delta 2.10(6 \mathrm{H}, \mathrm{q}, J=1.0 \mathrm{~Hz}), 6.56(2 \mathrm{H}, \mathrm{d}, J=1.0 \mathrm{~Hz}) ;{ }^{13} \mathrm{C} \mathrm{NMR}\left(\mathrm{CDCl}_{3} / \mathrm{TMS}\right): \delta \\
15.9,133.3,145.7,187.1 .\end{array}$ \\
\hline 2,5-Dimethyl-p-benzoquinone (5) & $\begin{array}{l}\text { Yield: } 90 \% \text {; Mp } 121-123{ }^{\circ} \mathrm{C} \text {; Lit. } 124-125^{\circ} \mathrm{C} \text { (Adam et al., 1994); CAS } 137-18-8 ;{ }^{1} \mathrm{H} \text { NMR } \\
(\mathrm{CDCl} / \mathrm{TMS}) \delta, J(\mathrm{~Hz}): 2.04(6 \mathrm{H}, \mathrm{d}, J=1,6 \mathrm{~Hz}), 6.60(2 \mathrm{H}, \mathrm{q}, J=1,6 \mathrm{~Hz}) ;{ }^{13} \mathrm{C} \mathrm{NMR}\left(\mathrm{CDCl}_{3} /\right. \\
\text { TMS): } \delta 15.6,133.3,145.7,188.7 .\end{array}$ \\
\hline Thymoquinone (6) & $\begin{array}{l}\text { Yield: } 93 \% \text {; Mp } 47-48{ }^{\circ} \mathrm{C} \text {; Lit. } 45-47{ }^{\circ} \mathrm{C} \text { (Dockal et al., 1985); CAS } 490-91-5 ;{ }^{1} \mathrm{H} \text { NMR } \\
\left(\mathrm{CDCl}_{3} / \mathrm{TMS}\right): \delta 1.13(6 \mathrm{H}, \mathrm{d}, J=6.8 \mathrm{~Hz}), 2.04(3 \mathrm{H}, \mathrm{d}, J=1.6 \mathrm{~Hz}), 3.03(1 \mathrm{H}, \mathrm{d} \text { hept, } J=1.2 \mathrm{e} \\
6.8 \mathrm{~Hz}), 6.52(1 \mathrm{H}, \mathrm{d}, J=1.2 \mathrm{~Hz}), 6.59(1 \mathrm{H}, \mathrm{q}, J=1.6 \mathrm{~Hz}) ;{ }^{13} \mathrm{C} \mathrm{NMR}\left(\mathrm{CDCl}_{3} / \mathrm{TMS}\right): \delta 15.3,21.4 \text {, } \\
26.5,130.3,133.8,145.1,154.9,187.4,188.5 .\end{array}$ \\
\hline
\end{tabular}

group at carbon 2) and compound 1, it is shown that the presence of a methyl group induces the loss of anticonvulsant activity. Interestingly, 2-isopropyl- $p$ benzoquinone 3 was bioactive $(p<0.01)$. This result suggests that bulky groups are important to preserve the pharmacological activity in monosubstituted parabenzoquinones. Similarly, anticonvulsant activity was maintained in both the dimethyl- $p$-benzoquinones 4 (methyl groups at carbons 2 and 6), and 5 (methyl groups at carbons 2 and 5). These results show that para-benzoquinones with two methyl groups attached to the ring are also bioactive. However, the comparison between the pharmacological effects of compounds $4(p<0.01)$ and $5(p<0.05)$ shows that changing the position of these groups in the ring may alter the anticonvulsant potency. Replacing the methyl group at carbon 2 by an isopropyl group as in thymoquinone $\mathbf{6}$ $(p<0.01)$, increases this activity, compared to compound 5 . This effect confirms that the presence of bulky alkyl groups attached to the ring enhances the anticonvulsant activity.

Most of the para-benzoquinones investigated in this study present pharmacological activity close to that of diazepam $(p<0.001)$, a standard anticonvulsant drug. PTZ is the prototype agent in the class of systemic convulsants, and is used as a screening test for anticonvulsant activity. The mechanism of action of PTZ is only partially understood. At a synaptic level PTZ appears to interact with the (GABA receptor-benzodiazepine-chloride ionophore) complex, decreasing the potency of inhibition and leading to seizures (Fisher, 1989). The enhancement of 
neural inhibition by GABA is a common therapeutic strategy for treating CNS diseases such as sleep disturbances, muscle spasms and seizure disorders (Chebib \& Johnston, 2000). Generally, compounds with anticonvulsant activity in petit mal epilepsy are effective in the PTZ-induced seizure model (Vida, 1995).

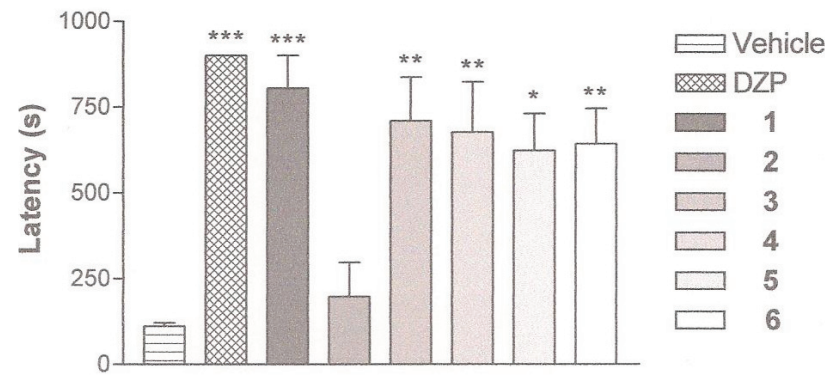

Figure 1. Effect of para-benzoquinones $(80 \mathrm{mg} / \mathrm{kg})$ on the latency of the first post-injection convulsion induced by pentylenetetrazol. The bars indicate mean \pm S.E.M. $(n=8)$. Statistically significant differences $* p<0.05, * * p<0.01$, $* * * p<0.001$ with respect to control according to one-way ANOVA, followed by Dunnett's test.

However, using Structure-Activity Relationships knowledge, we identified structural characteristics which may contribute to the understanding of the anticonvulsant activity of quinones and their derivatives. It was found that the presence of alkyl groups attached to the ring influence the pharmacological activity of the para-benzoquinones. In addition, the number, position, and size of these groups change the potency of the compounds. Factors such as lipophilicity may be related to these anticonvulsant potency differences. Our experimental results also suggest that by appropriate structural modification of parabenzoquinones it may be possible to develop novel anticonvulsant drugs potentially suitable to control seizures.

\section{Acknowledgment}

The authors are grateful to the $\mathrm{CNPq}$ and FAPESP for providing financial support.

\section{References}

Acros Organics 2007/2008. Catalog of Organic and Fine Chemicals, Fisher Scientific, 282: 1927.

Adam W, Herrmann WA, Lin J, Saha-Möller CR 1994. Catalytic oxidation of phenols to $p$-quinones with the hydrogen peroxide and methyltrioxorhenium(VII) System. J Org Chem 59: 8281-8283.

Ali BH, Blunden G 2003. Pharmacological and toxicological properties of Nigella sativa. Phytother Res 17: 299-
305.

Almeida RN, Motta SC, Leite JR 2003. Óleos essenciais com propriedades anticonvulsivantes. Bol Latinoam Caribe Plantas Med Aromat 2: 3-6.

Barton DHR, Finet J-P, Thomas M 1988. Comparative oxidation of phenols with benzeneseleninic anhydride and with benzeneseleninic acid. Tetrahedron 44: 6397-6406.

Chebib M, Johnston GAR 2000. GABA-activated ligand gated ion channels: Medicinal chemistry and molecular biology. J Med Chem 43: 1427-1447.

Clement JA, Yoder BJ, Kingston DGI 2004. Natural products as a source of CNS-active agents. Mini-Rev Org Chem 1: 183-208.

De Almeida RN, De Sousa DP, Nóbrega FFF, Claudino FS, Araújo DAM, Leite JR, Mattei R 2008. Anticonvulsant effect of a natural compound $\alpha, \beta$-epoxy-carvone and its action on the nerve excitability. Neurosci Lett 443 : 51-55.

De Sousa DP, Quintans JL, Almeida RN 2007. Evolution of the anticonvulsant activity of alfa-terpineol. Pharm Biol 45: 69-70.

De Sousa DP, Gonçalves JCR, Quintans-Júnior L, Cruz JS, Araújo DAM, De Almeida RN 2006. Study of anticonvulsant effect of citronellol, a monoterpene alcohol, in rodents. Neurosci Lett 401: 231-235.

Dewick PM 2001. Medicinal Natural Products. A Biosynthetic Approach. 2nd ed., Chichester: John Wiley \& Sons Ltd, pp. 158-164.

Dockal ER, Cass QB, Brocksom TJ, Brocksom U, Corrêa AGA 1985. Simple and efficient synthesis of thymoquinone and methyl $p$-benzoquinone. Synth Commun 15: 10331036.

Engel J 1995. Concepts of epilepsy. Epilepsia 36: 23-30.

Fisher RS 1989. Animal models of the epilepsies. Brain Res Rev 14: 245-278.

Hosseinzadeh H, Parvardeh S 2004. Anticonvulsant effects of thymoquinone, the major constituent of Nigella sativa seeds, in mice. Phytomedicine 11: 56-64.

Hosseinzadeh H, Parvardeh S, Nassiri-Asl M, Mansouri M 2005. Intracerebroventricular administration of thymoquinone, the major constituent of Nigella sativa seeds, suppresses epileptic seizures in rats. Med Sci Monit 11: BR106-110.

Ilhan A, Gurel A, Armutcu F, Kamisli S, Iraz M 2005. Antiepileptogenic and antioxidant effects of Nigella sativa oil against pentylenetetrazol-induced kindling in mice. Neuropharmacology 49: 456-464.

Raza M, Alghasham AA, Alorainy MS, El-Hadiyah TM 2006. Beneficial interaction of thymoquinone and sodium valproate in experimental models of epilepsy: reduction in hepatotoxicity of valproate. Sci Pharm 74: 159-173.

Saladino R, Neri V, Mincione E, Filippone P 2002. Selective oxidation of phenol and anisole derivatives to quinones 
with hydrogen peroxide and polymer-supported methylrhenium trioxide systems. Tetrahedron 58: 8493-8500

Sander JWAS, Shorvon SD 1996. Epidemiology of epilepsies. J Neurol Neurosurg Psychiatry 61: 433-443.

Swinyard EA, Woodhead JH, White HS, Franklin MR 1989.

Experimental selection, quantification and evaluation of anticonvulsants. In Levy RH, Dreyfuss FE, Mattson RM, Meldrum BS, Penry JK (Eds.). Antiepileptic drugs. New York: Raven Press, p. 85.

Tyagi A, Delanty N 2003. Herbal remedies, dietary supplements, and seizures. Epilepsia 44: 228-235.

Uliana MP, Vieira YW, Donatoni MC, Corrêa AG, Brocksom U, Brocksom TJ 2008. Oxidation of mono-phenols to para-benzoquinones: a comparative study. $J$ Braz Chem Soc 19: 1484-1489.

Vida JA 1995. Anticonvulsants. In Foye WO, Lemke TL, Williams DA(Eds.). Principles of medicinal chemistry. London: Williams and Wilkins, pp. 182-198.

\section{*Correspondence}

Damião P. de Sousa

Laboratório de Química de Produtos Naturais e Sintéticos Bioativos, Departamento de Fisiologia

Universidade Federal de Sergipe, 49100-000 São CristóvãoSE, Brazil

desousa@ufs.br

Tel. +55 7921056843 